\title{
Analysis of the factors that restrict the development of third party logistics and trend of Small and medium-sized enterprises
}

\author{
Wang Hongwei \\ Xijing University, Xi’an, 710123, China
}

Keywords: small and medium-sized enterprises; the third party logistics; the strategic alliance

\begin{abstract}
The third party logistics is to regulate the relationship between logistics operators and logistics consumers through the form of contract. Small and medium-sized industrial enterprises reform under the guidance of the country's "supporting small" policy, the implementation of the financial credit policy to small and medium-sized industrial enterprises, guiding the small and medium enterprises restructuring, reform and development, the development and change of the society will become the external environmental impact factors of small and medium-sized enterprises. According to the current situation of the development of third party logistics in China at present, enterprises should be from the following aspects: to start the training of professional logistics management personnel, update the logistics concept, propaganda and establish modern logistics management concepts, improve the level of logistics services, apply of modern logistics information technology, strengthen the enterprise focus and strategic alliance, focus on service development strategy, the government should strengthen the infrastructure construction, create a favorable market environment for the development of the third party logistics.
\end{abstract}

\section{Introduction}

Third party logistics is relative to the "first party" of the shipper and the "second party" of the consignee. It is a kind of logistics form that the third party professional enterprises undertake the logistics activities of enterprises. It provides customers logistics agency services with the contract as the constraint, based on the alliance, a series of personalized, information-based. With the development of information technology and the trend of economic globalization, more and more products are circulated, produced, sold and consumed in worldwide, logistics system increasingly large and complex, and the logistics organization and operation mode of the first party and the second party has been unable to fully meet the needs of the society; at the same time, to participate in the world competition, enterprises must establish core competitiveness, strengthen the supply chain management, reduce logistics costs, put out the contract does not belong to the core business of logistics activities. Thus, the third party logistics was born. 3PL does not belong to the first party, does not belong to the second party, but through cooperating with the first or the second party to provide professional logistics services, it has no goods, do not participate in the sale of goods, but to provide series, personalized information logistics service that is based on the contract and alliance as the basis for customers. The most common 3PL services including the design of logistics system, EDI capabilities, report management, cargo container transport, select the carrier, freight 
forwarding, customs agents, information management, storage, consultation, payment of freight, freight negotiations. Because the service generally signed with the enterprise a certain period of logistics service contract, so some people called the third party logistics as contract logistics.

\section{Characteristics of third party logistics}

From the development of the logistics industry in developed countries, the third party logistics in the development has gradually formed a distinctive feature, outstanding performance in the following five aspects:

Contractual relationship. First of all, the third party logistics uses contract to regulate the relationship between logistics operators and logistics consumers. According to the requirements of the contract, the logistics operator provides a multi-functional and even integrated logistics service. Secondly, the development of the third party logistics alliance uses contract to clear the rights and responsibilities of the participants in the logistics alliance.

Personalized service. First of all, different consumers have different logistics service requirements, the third party logistics according to the different requirements of different consumers in the logistics enterprise image, business processes, product characteristics, customer characteristics, competition and other aspects, to provide targeted personalized logistics services and value-added services. Secondly, the third party logistics operators need to form the core business because of the impact of market competition, logistics resources and logistics capability, continue to strengthen the personality and characteristics of the logistics services, enhance the city logistics competitiveness.

Professional function. The third party logistics provides professional logistics services. It must reflect the specialized and professional level from the logistics design, logistics operations, logistics technology, facilities and tools to logistics management, which is the needs of logistics of consumers, and also the basic requirements of the third party logistics development.

System management. The third party logistics should have the system function of the logistics, which is the basic requirement of the development and development of the third party logistics, and the establishment of the modern management system should meet the basic requirements of the operation and development of the third party logistics.

Information and networking. Information technology is the foundation of the development of third party logistics. In the process of logistics service, the development of information technology has realized the sharing of information in real time, promoted the scientific management of logistics, and greatly improved the efficiency of logistics and logistics.

\section{The restrictive factors of the third party logistics in China's small and medium sized enterprises.}

At present, the main reason of restricting the development of the third party logistics is the following aspects:

Under the guidance of country's "small supporting” policy, small and medium sized industrial enterprises reformed, the national plays credit financial policy on small and medium-sized industrial enterprises. The market competition and the development of the society will be the external environmental factors. However, small and medium industrial enterprises have adopted the "big and complete" and "small and complete" mode production and management concept, logistics activities and organization management is in the segmentation and closed condition, it must have an important influence on the internal development of the third party logistics, mainly for:

Influence of idea. The small and medium-sized industrial enterprises generally practice single production and management, the business scope of the enterprise is closed, lacking of integration 
into the market and social mode, enterprises are accustomed to the traditional storage methods, pay attention to the production and neglecting of storage and transportation, it is difficult to form the modern logistics management theory, is the wrong understanding of third party logistics, this is the fundamental factor affecting the development of the third party logistics.

Influence of structure. There are a large number of small and medium-sized enterprises of small area, the total size is not small, but the organization and the industrial structure is unreasonable, the low level of duplication, duplication of investment, products are oversupply in many industries, widespread that industry related degree is low, is lack of labor division and cooperation with socialization and specialization, this is important the influence factors of the third party logistics development.

Influence technical factors. Although the information industry has injected a large number of high technique into small and medium-sized enterprises, but the resource and technology structure is not reasonable, facilities and equipments are old, low level of logistics technology, difficult to adapt to the development of professional logistics modernization, it is the main factor affecting the development of third party logistics.

Influence of management factors. The majority of small and medium-sized industrial enterprises are lack of the scientific internal management system, lack of the ability to manage and organization, production management and organization operation are in a state of confusion. There is no market research before production, there is no strict cost accounting, no production control, no marketing strategy, no after-sales service after production, this is the basic factors which restrict the development of the third party logistics.

Influence of talent factor. In small and medium-sized enterprises there are low quality of employees, the knowledge structure is unreasonable, is lack of talent, lack of innovation ability.

\section{The basic mode of third party logistics in China}

According to the development of logistics and the basic practice of logistics development in China, the basic methods of developing the third party logistics in China can be divided into the following categories:

First of all, a gradual development mode can be considered, by the growing number of its logistics business, accumulate resources and management experience, to become professional integrated logistics operators, to provide comprehensive logistics services for small and medium sized enterprises.

Secondly, we can consider the development by leaps and bounds, through the alliance contract to integrate resources with and small and medium enterprises, rapid expansion of logistics capacity, unconventionally become a professional third party logistics enterprise.

(1) Policy approach. To develop the third party logistics in small and medium-sized enterprises in has some obstacles for logistics enterprises, all levels of government need to formulate policies and positive guidance to encourage, from the credit, financial, policy and other aspects to create a conducive policy environment for the development, and really to support and guide small and medium-sized enterprises to actively restructure and use resources, start and promote the development of the third party logistics in small and medium sized enterprises.

(2) Market approach. With the development of small and medium enterprises, logistics demand is growing, logistics enterprises should study the law of the development of small and medium enterprises logistics, demand oriented, to develop the third party logistics rapidly and effectively.

(3) Business approach. Logistics development can create value and benefit, and it is the basic motive force of developing the third party logistics.

(4) Social approach. The development of the third party logistics need the whole society's active 
cooperation and support, in the role of social forces realize the realization of industrial linkage and comprehensive development.

\section{Development strategy of third party logistics in small and medium sized enterprises in china.}

Based on the current situation of China's small and medium-sized enterprises, the development strategy of the third party logistics in China should highlight the following points:

(1) Resource strategy. Developing third party logistics, the logistics enterprises need to focus on grasping and effectively use business resources, mainly displays in: firstly, understand correctly and analyze in-depth of the based situation of business resources, correctly choice the development direction of third party logistics. Secondly, actively explore the effective allocation of enterprise resources, and effectively promote the development of the third party logistics. Finally, study the sustainable development of enterprise resources, and ensure the healthy development of the third party logistics. Therefore, small and medium-sized enterprises implement strategic resources, with supply chain management to reconstruct the business process, to build the third party logistics development advantages; should grasp the mode of resource conversion, and continuously improve the efficiency of resource output.

(2) Alliance strategy. The development of logistics enterprises of third party logistics needs the "complementary advantages, benefit sharing" principle, with the aid of property rights, contract to achieve mutual cooperation and common to development of logistics market, reduce logistics cost, improve the efficiency of the logistics. The first one is the alliance of logistics resources: combine the scattered logistics and logistics functions of the small and medium-sized industrial enterprises through a certain factors to form a resources advantage of logistics integration. The second one is the alliance of logistics geographical region and the scope of the industry: according to the characteristics of small and medium enterprises in all walks of life, to apply the logistics industry alliance in a certain geographical area or a certain range, forming an efficient operation system. Finally, develop the third party logistics alliance with the establishment of small and medium enterprises, through the formation of service associations, coordinate and guide the relationship between logistics enterprises and small and medium industrial enterprises in the development of the third party logistics.

(3) Service strategy. Logistics enterprises to develop the third party logistics must rely on the development of small and medium industrial enterprises, so that "from small and medium enterprises, service to small and medium enterprises". Four main points: Firstly, to design and provide personalized logistics service concept based on the actual needs of small and medium industrial enterprises. Secondly, must pay attention to the change of market demands and provide service measures to ensure the quality of enterprise products. Thirdly, we must deeply understand the logistics law of small and medium enterprises to establish a perfect logistics operation and management service efficiency.

\section{The development trend of the third party logistics in China}

At present, the proportion of China's third party logistics in the logistics market is only about $10 \%$. There are not a large number of professional third party logistics enterprises, which is the weakest link in the current logistics development, and also restricts the development of China's economy. The scale of China's third party logistics market is in 60 billion Yuan to 70 billion Yuan, they are not only small but also highly dispersed. in the third party logistics enterprises of the number 10 to 15 thousand, no company accounted for more than $2 \%$ market share, most logistics companies are in the a small limited part of supply chain function, can not meet the customers' 
logistics integration service needs. President of brocade information which is the largest logistics supply chain management software provider in China Shen Guokang pointed out that because most of the logistics enterprises transformed from the original transportation industry, most of which did not form the core competitiveness of enterprises, technical level and management level is not high, lacking of logistics service standards. Although the number of logistics companies and the base investment has soared around, but the vicious competition seriously disrupted the market order, resulting in poor performance of general logistics companies, lacking of development potential. Use information technology to improve the quality and efficiency of transport, improve service capabilities to customers, so as to enhance the core competitiveness, this is the inevitable choice of many third party logistics enterprises to deal with market competition.

The third party logistics enterprise information construction goal should be the whole enterprise supply chain management, to implement enterprise level information system construction. In order to cross the boundaries of the department, to achieve interoperability of the data and information in various departments, and on this basis, to realize centralized information query and centralized distribution. The third party logistics enterprises in our country should learn from the experience of western developed countries third party logistics development, extensive take use of computer technology and communication technology to improve the enterprise's own transport efficiency and service ability, enhance core competitiveness, and only by this way can the enterprises be bigger and stronger in the market competition.

\section{Conclusion}

In this paper, the development of the third party logistics enterprises is analyzed and some solutions are put forward. First of all, the concept of third party logistics is backward in our country, most of the enterprises refused to adopt the third party logistics service, especially in the traditional enterprise, their management ideas and management methods are obsolete. Secondly, we are lacking of professional technology of the third party logistics in China. According to the current situation of the development of third party logistics in China, China's enterprises should do the following aspects: train for professional logistics management personnel, update the logistics concept, through the propaganda to set up the modern logistics management concepts, improve the level of logistics services, apply modern logistics information technology, strengthen the enterprise focus and strategic alliance, focus on the implementation of service development strategy. The government should also strengthen the infrastructure to create a good market environment for the development of the third party logistics.

\section{References}

[1] Rui Guijie. Development strategy of third party logistics. China financial and Economic Publishing house.2009.2

[2] Chen Yaping, Zhu Guojun. The development of third party logistics in china. 2008.11

[3] Cui Gang. Study on the current situation and development strategy of third party logistics in china. Heilongjiang traffic science and technology. 2010.

[4] Yao jia. Analysis on the development strategy of third party logistics enterprises in China. Economic Research guide. 2008.

[5] Yan Hongwei. Current situation and development trend of third party logistics in China. Academic discussion. 2009.

[6] Li Guofeng. Analysis on the advantages and disadvantages of third party logistics in china. Harbin Institute of Technology press. 2009.9. 